Phys̄ìcs

\title{
To Touch the Sun
}

Jorge Cham, aka, PHD Comics, illustrates the daring mission of the Solar

Parker Probe, which flew closer to the Sun than any previous spacecraft.

Jorge Cham 


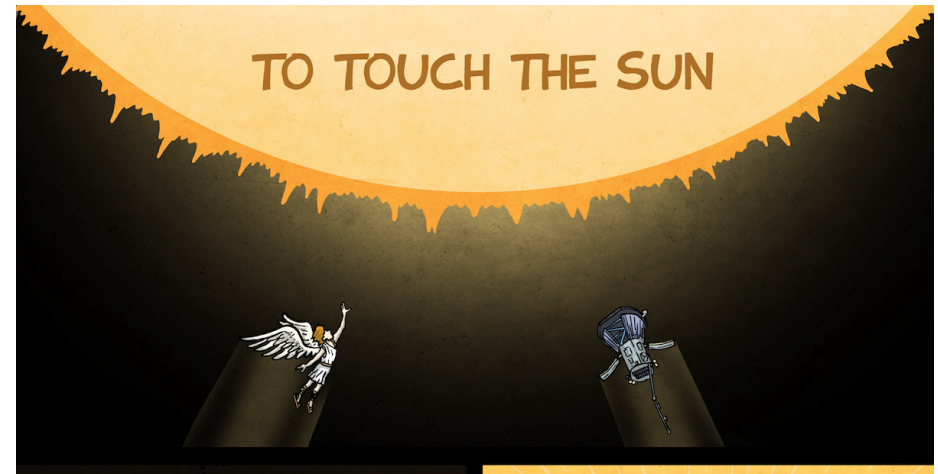

AT ITS CORE, THE SUN IS A TOASTY 15.7 MILLION DEGREES CELSIUS.

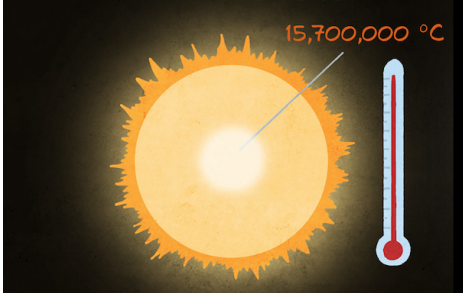

THE RADIATION TRAVELS OUTWARDS HUNDREDS OF THOUSANDS OF MLES, THEN ENTTERS THE CONVECTVE HEN ENTERS THE CONVECTV LAYERS OF THE SUN, WHERE CHURNING COLUMNS OF PLASMA CARRY THE HEAT TO THE SURFACE.

Radiative Layer

\section{Convective}

Layer

Photosphere

WHLE THE SURFACE OF THE SUN IS AT 5,500 DEGREES, THE SUN'S ATMOSPHERE IS ACTUALY HOTTER REACHING TEMPERATURES OF UP TO $1,000,000$ DEGREES.

WHY IS THE OUTSIDE OF THE SUN HOTTER THAN ITS SURFACE?

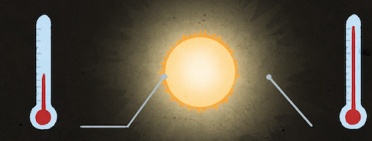

5,500

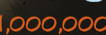

IN 2018, THE PARKER SOLAR PROBE LEFT EARTH TO FLY CLOSER TO THE SUN THAN ANY HUMAN-MADE OBJECT HAS EVER DONE BEFORE.
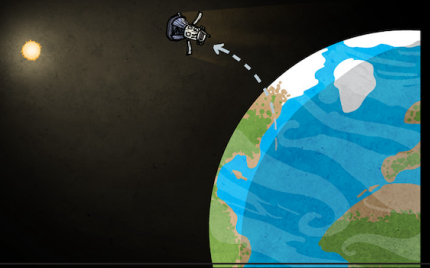

I'S ALSO HAKD TO GET TO THE SUN. NOT JUST BECAUSE THE SUN IS FAR, BUT BECAUSE THE EARTH IS MOVINE SO FAST.
THE INTENSE GRAVITY CAUSES HYDROGEN TO FUSE INTO HELIUM, RELEASING VAST AMOUNTS OF ENERGY.

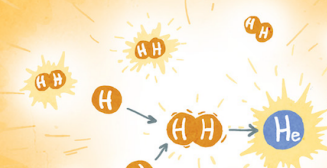

(1)

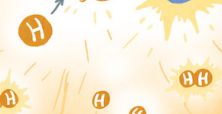

(1) (1)

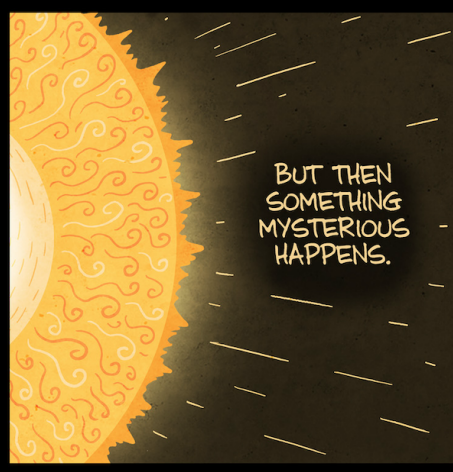

IT TURNS OUT, THERE'S STLL A LOT WE DON'T KNOW ABOUT HOW THE SUN WORKS.

TO LEARN MORE, WE NEED TO GET CLOSER TO IT.

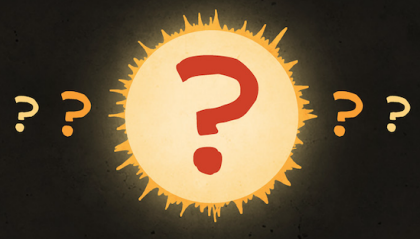

BUT FLYING CLOSE TO THE SUN IS NOT AN EASY TASK

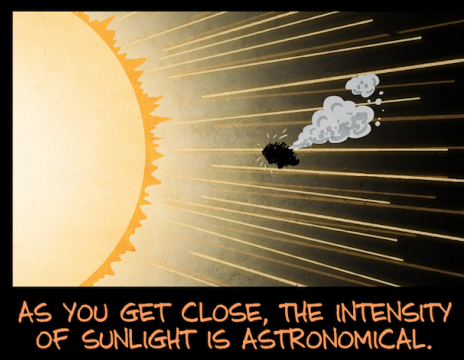

ANY SPACECRAFT LEAVING EARTH NEEDS TO SPEND HUGE AMOUNTS OF ENERGY TO SLOW DOWN ENOUEH TO FALL INTO A SMALLER ORBIT. 